\title{
Application of structural equation modelling to analyse the impacts of logistics services on risk perception, agility and customer service level
}

\author{
Avelar-Sosa, L., ${ }^{a,}$, , García-Alcaraz, J.L. ${ }^{b}$, Maldonado-Macías, A.A. ${ }^{c}$, Mejía-Muñoz, J.M. ${ }^{d}$ \\ a,b,c Department of Industrial and Manufacturing Engineering, Autonomous University of Ciudad Juarez, Mexico \\ ${ }^{d}$ Department of Electrical and Computing Engineering, Autonomous University of Ciudad Juarez, Mexico
}

\begin{abstract}
A B S T R A C T
Logistics services of manufacturing enterprises help to improve transport, delivery of materials and finished products. This paper presents a causal model to identify the influence that has the availability of logistics services on the risk perception, on agility and on customer service level of manufacturing companies. A questionnaire was developed, validated and applied to 225 employees of different industrial sectors. Information is integrated in a structural equation model for test seven hypotheses using partial least squares to calculate the regression coefficient between variables using $95 \%$ confidence level. The results mainly indicated that the availability of logistics services have a positive and direct effect on risk in demand and in supplier's risk; but in addition, agility and transportation also have effects over them. All these variables have direct or indirect contributions on customer service level and can explain $45 \%$ of its variability. On the other hand, it is also identified that transportation performance has a direct effect on agility 0.42 standard deviation units. Findings in this paper demonstrate quantitatively through a statistical analysis the importance of infrastructure for logistic services available in the regions, the role of transportation and its impact on risk in suppliers and agility, and how customer services can be improved increasing supply chain agility and diminishing the risk in demand.
\end{abstract}

\author{
ARTICLE INFO \\ Keywords: \\ Logistics services; \\ Perception risk; \\ Customer service; \\ Agility; \\ Supply chain \\ *Corresponsal author: \\ liliana.avelar@uacj.mx \\ (Avelar-Sosa, L.) \\ Article history: \\ Received 27 June 2017 \\ Revised 2 June 2018 \\ Accepted 4 June 2018
}

\section{References}

[1] Vikulov, V., Butrin, A. (2014). Risk assessment and management logistics chains, LogForum, Vol. 1, No. 10, 43-49.

[2] Hoffmann, P., Schiele, H., Krabbendam, K. (2013). Uncertainty, supply risk management and their impact on performance, Journal of Purchasing and Supply Management, Vol. 19, No. 3, 199-211, doi: 10.1016/j.pursup.2013. $\underline{06.002}$.

[3] Jereb, B., Cvahte, T., Rosi, B. (2012). Mastering supply chain risks, Serbian Journal of Management, Vol. 7, No. 2, 271-285, doi: $10.5937 / \operatorname{sim} 7-1360$.

[4] Merschmann, U., Thonemann, U.W. (2010). Supply chain flexibility, uncertainty and firm performance: An empirical analysis of German manufacturing firms, International Journal of Production Economics, Vol. 130, No. 1, 4353, doi: 10.1016/j.ijpe.2010.10.013.

[5] Hu, H., Shi, L., Ma, H., Ran, B. (2017). Stability of the supply chain based on disruption classification, Tehnički vjesnik - Technical Gazette, Vol. 24, No. 4, 1187-1195, doi: 10.17559/TV-20170723084826. 
[6] Gligor, D.M, Holcomb, M.C., Stank, T.P. (2013). A multidisciplinary approach to supply chain agility: Conceptualization and scale development, Journal of Business Logistics, Vol. 34, No. 2, 94-108, doi: 10.1111/jbl.12012.

[7] Bhatnagar, R., Sohal, A.S. (2005). Supply chain competitiveness: Measuring the impact of location factors, uncertainty and manufacturing practices, Technovation, Vol. 25, No. 5, 443-456, doi: 10.1016/j.technovation.2003. $\underline{09.012 .}$.

[8] Christopher, M. (2005). Logistics and supply chain management: Creating value-added networks, 3rd edition, Prentice Hall, USA.

[9] Ernst, R., Kamrad, B. (2000). Evaluation of supply chain structures through modularization and postponement, European Journal of Operational Research, Vol. 124, No. 3, 495-510, doi: 10.1016/S0377-2217(99)00184-8.

[10] Russell, R.S., Taylor III, B.W. (2010). Operations management: Creating value along the supply chain, 7th edition, John Wiley \& Sons, USA.

[11] Li, X., Goldsby, T.J., Holsapple, C.W. (2009). Supply chain agility: Scale development, The International Journal of Logistics Management, Vol. 20, No. 3, 408-424. doi: 10.1108/09574090911002841.

[12] Costantino, N., Dotoli, M., Falagario, M., Fanti, M.P., Mangini, A.M. (2012). A model for supply management of agile manufacturing supply chains, International Journal of Production Economics, Vol. 135, No. 1, 451-457, doi: 10.1016/i.ijpe.2011.08.021.

[13] Bhatnagar, R., Jayaram, J., Phua, Y.C. (2003). Relative importance of plant location factors: A cross national comparison between Singapore and Malaysia, Journal of Business Logistics, Vol. 24, No. 1, 147-170, doi: 10.1002/ j.2158-1592.2003.tb00035.x.

[14] Yang, J. (2014). Supply chain agility: Securing performance for Chinese manufacturers, International Journal of Production Economics, Vol. 150, 104-113, doi: 10.1016/j.ijpe.2013.12.018.

[15] Wilson, C. (2016). Growing together: Economic ties between the United States and Mexico, A regional manufacturing platform, Washington, DC., The Wilson Center Mexico Institute, from https://www.wilsoncenter.org/sites/default/files/a regional manufacturing platform.pdf accessed June 2, 2018.

[16] Swafford, P.M., Ghosh, S., Murthy, N. (2006). The antecedents of supply chain agility of a firm: Scale development and model testing, Journal of Operations Management, Vol. 24, No. 2, 170-188, doi: 10.1016/i.jom.2005.05.002.

[17] Wu, T., Blackhurst, J., Chidambaram, V. (2006). A model for inbound supply risk analysis, Computers in Industry, Vol. 57, No. 4, 350-365, doi: 10.1016/i.compind.2005.11.001.

[18] Hallikas, J., Karvonen, I., Pulkkinen, U., Virolainen, V.-M., Tuominen, T. (2004). Risk management processes in supplier networks, International Journal of Production Economics, Vol. 90, No. 1, 47-58, doi: 10.1016/i.ijpe.2004. $\underline{02.007}$.

[19] Lu, C.-S., Lai, K.-H., Cheng, T.C.E. (2007). Application of structural equation modeling to evaluate the intention of shippers to use Internet services in liner shipping, European Journal of Operational Research, Vol. 180, No. 2, 845-867, doi: 10.1016/j.ejor.2006.05.001.

[20] Kroes, J.R. (2007). Outsourcing of supply chain processes: Evaluating the impact of congruence between outsourcing drivers and competitive priorities on performance, Doctoral thesis, Georgia Institute of Technology, USA.

[21] Chong, A.Y.-L., Ooi, K.-B., Sohal, A. (2009). The relationship between supply chain factors and adoption of ecollaboration tools: An empirical examination, International Journal of Production Economics, Vol. 122, No. 1, 150-160, doi: 10.1016/j.ijpe.2009.05.012.

[22] Tang, C., Tomlin, B. (2008). The power of flexibility for mitigating supply chain risks, International Journal of Production Economics, Vol. 116, No. 1, 12-27, doi: 10.1016/j.ijpe.2008.07.008.

[23] Jamshidi Navid, B., Ismaeli, S. (2012). Analyzing effective elements in agile supply chain, Management Science Letters, Vol. 2, No. 1, 369-378, doi: 10.5267/j.msl.2011.07.008.

[24] Wiengarten, F., Pagell, M., Fynes, B. (2012). Supply chain environmental investments in dynamic industries: Comparing investment and performance differences with static industries, International Journal of Production Economics, Vol. 135, No. 2, 541-551, doi: 10.1016/i.ijpe.2011.03.011.

[25] Gunasekaran, A., Kobu, B. (2007). Performance measures and metrics in logistics and supply chain management: A review of recent literature (1995-2004) for research and applications, International Journal of Production Research, Vol. 45, No. 12, 2819-2840, doi: 10.1080/00207540600806513.

[26] Nordgaard, A., Ansell, R., Jaeger, L., Drotz, W. (2010). Ordinal scales of conclusions for the value of evidence, Science \& Justice, Vol. 50, No. 1, 31, doi: 10.1016/j.scijus.2009.11.025.

[27] Nunnally, J., Bernstein, I. (1994). Psychometric theory, 3rd edition, McGraw-Hill, New York, USA.

[28] Avelar-Sosa, L., García-Alcaraz, J.L., Cedillo-Campos, M.G., Adarme-Jaimes, W. (2014). Effects of regional infrastructure and offered services in the supply chains performance: Case Ciudad Juarez, Dyna, Vol. 81, No. 186, 208217, doi: $10.15446 /$ dyna.v81n186.39958.

[29] Martínez Sánchez, A., Pérez Pérez, M. (2005). Supply chain flexibility and firm performance: A conceptual model and empirical study in the automotive industry, International Journal of Operations \& Production Management, Vol. 25, No. 7, 681-700, doi: 10.1108/01443570510605090.

[30] García-Alcaraz, J.L., Maldonado-Macías, A.A., Alor-Hernández, G., Sánchez-Ramírez, C. (2017). The impact of information and communication technologies (ICT) on agility, operating, and economical performance of supply chain, Advances in Production Engineering \& Management, Vol. 12, No. 1, 29-40, doi: 10.14743/apem2017.1.237.

[31] Wieland, A., Wallenburg, C.M. (2012). Dealing with supply chain risks: Linking risk management practices and strategies to performance, International Journal of Physical Distribution \& Logistics Management, Vol. 42, No. 10, 887-905, doi: $10.1108 / 09600031211281411$.

[32] Cenfetelli, R.T., Bassellier, G. (2009). Interpretation of formative measurement in information systems research, Mis Quarterly, Vol. 33, No. 4, 689-707, doi: 10.2307/20650323. 
[33] Petter, S., Straub, D., Rai, A. (2007). Specifying formative constructs in information systems research, Mis Quarterly, Vol. 31, No. 4, 623-656, doi: 10.2307/25148814.

[34] Hair Jr, J.F., Hult, G.T.M., Ringle, C., Sarstedt, M. (2016). A primer on partial least squares structural equation modeling (PLS-SEM), Sage Publications, USA.

[35] Pérez, E., Medrano, L.A., Sánchez Rosas, J. (2013). El path analysis: Conceptos básicos y ejemplos de aplicación, Revista Argentina de Ciencias del Comportamiento, Vol. 5, No. 1, 52-66. 